\title{
Outsourcing and performance of inbound logistics for the automobile industry
}

\author{
Myoung-Kang Heo, Yong Jin Kim ${ }^{* *}$ and Min-Sung Kim ${ }^{* * *}$
}

\begin{abstract}
The studies focusing on inbound logistics in the automobile industry have been limited because of the relatively small portion of logistics cost. But now it is recognized as one of the critical factors for efficient execution of supply chain management (SCM). The survey of suppliers in the automobile industry conducted in this study indicated significant relationships among logistics performance, logistics outsourcing, and performance evaluation level. This research is three-fold. First, current status of part supplier's logistics was analyzed by interviews with inbound logistics providers and suppliers. Second, management type of logistics was analyzed. There were three kinds of logistics -two kinds of logistics outsourcing and direct control by the supplier. Each type of logistics management showed differences about performance. Third, logistics performance evaluation and its relation with the actual logistics performance were presented. Comparable performance evaluation factors were selected, and it is shown that they had a correlation with actual performance.
\end{abstract}

Keywords: Inbound logistics, Part supplier, Automobile industry, Logistics performance, Outsourcing.

\section{Introduction}

Even though the automobile industry is very significant in Korea, the studies dealing with logistics in the automobile industry were very few. Especially, relatively little attention was given

Submission Date: 29/09/2007

Acceptance Date: 13/11/2007

* Graduate Student, Inha University, 253 Yonghyun-dong, Nam-Gu Incheon 402-751, Korea.

*** Corresponding Author, Assistant Professor, Asia Pacific School of Logistics, Inha University, 253 Yonghyun-dong, NamGu Incheon 402-751, Korea. E-mail: yongin@inha.ac.kr

Assistant Professor, Graduate School of Logistics, Inha University, 253 Yonghyun-dong, Nam-Gu Incheon 402-751, Korea.E-mail:minskim@inha.ac.kr 
to inbound logistics because the logistics cost for the automobile industry was considered trivial. As logistics innovation strategies such as JT strategy were propagated, logistics, particularly inbound logistics, is concerned more and more these days.

The Korean automobile industry is the fifth largest in the world in terms of production volume, sixth largest in export volume. From January to November in 2006, the number of vehicles for export was 2.67 millions (sales: 43 billion dollar). The automobile industry continually ranked first in the amount of export, and the number of new job creations in Korea.

In manufacturing, a well managed supply chain is critical; getting all the required parts and raw materials in the right sequence, the right quantity, the right quality and the right time to the manufacturing and assembly plants. In an effort for the cost-effective and flexible part supply, inbound logistics is the most important sector.

Even though outsourcing of inbound logistics in the automobile industry has a long history and is one of the first cases of outsourcing logistics to 3PL, it is surprising to note that the benefits of 3PL in the automobile industry are often addressed but rarely captured in the research context.

On the other hand, logistics performance evaluation criteria and its implementation is an essential part for companies. In this regard, several studies suggested various logistics performance indices, and many companies have adopted those indices selectively. As a result, each company/industry uses different performance indices, which makes it difficult to compare the performance level for each company/industry. Company size makes this matter worse, since small companies, in general, manage performance evaluation very poorly. So, comparable and suitable performance evaluation should be applied for the automobile industry.

Based on the previous facts, this study intended to answer the questions, such as: (1) What is the current trend of inbound logistics in the automotive industry? (2) What are the problems of right time, right quantity delivery? (3) What are the main factors when selecting the inbound logistics outsourcing? (4) What are the differences between supplier's type of logistics in terms of the performance evaluation levels? (5) What are the differences between supplier's type of logistics in terms of the actual logistics performance?

\section{Research Background}

This section is composed of four parts. First of all, Korean automobile suppliers are introduced to present the big picture of part suppliers-automobile manufacturers' relationship in Korea. Secondly, some significant characteristics of logistics in the automobile industry are listed to understand automobile industry specific features and the current status of inbound logistics in Korea. Then, previous studies dealing with inbound logistics in the automobile industry are investigated and summarized. Lastly, the studies regarding logistics performance measurement are reviewed to list out the relevant performance indicators. 


\subsection{Automobile Component Suppliers in Korea}

In 2005, there were 922 1st suppliers in Korea. Among them, 836 were medium-small sized companies and 86 were big sized companies. This distinction was made by the number of employees (less than 300) and capital (less than 80 hundred millions).

In terms of each automobile manufacturer's suppliers, Hyundai and Kia have 377 and 391 suppliers, respectively (Table 1). Those numbers are more than two times that of Renault-Samsung's suppliers. It is not a manufacturer's level of modularization, but simply the number of manufacturing models.

Table 1

Number of manufacturer's suppliers

\begin{tabular}{c|c|c|c|c|c|c|c|c}
\hline Year & Hyundai & Kia & $\begin{array}{c}\text { GM- } \\
\text { Daewoo }\end{array}$ & $\begin{array}{c}\text { Ssang } \\
\text { yong }\end{array}$ & $\begin{array}{c}\text { Renault } \\
\text { Samsung }\end{array}$ & $\begin{array}{c}\text { Daewoo } \\
\text { Bus }\end{array}$ & $\begin{array}{c}\text { Daewoo } \\
\text { Truck }\end{array}$ & Total \\
\hline \hline 2004 & 373 & 396 & 281 & 240 & 152 & 174 & 188 & $1804\left(913^{*}\right)$ \\
2005 & 377 & 391 & 307 & 237 & 146 & 178 & 192 & $1828\left(922^{*}\right)$ \\
\hline
\end{tabular}

Note: *actual number of suppliers

On the other hand, table 2 shows the purchasing cost among the sales sector. It should be noted that GM-Daewoo and Kia have larger portions $(63.6 \%, 61.5 \%)$ than others, which might indicate the importance of supply management.

Table 2

Parts purchasing cost

(Hundred million won)

\begin{tabular}{l|c|c|c|c|c|c}
\hline & \multicolumn{3}{|c|}{2004} & \multicolumn{3}{c}{2005} \\
\cline { 2 - 7 } & $\begin{array}{c}\text { Sales } \\
\text { (A) }\end{array}$ & $\begin{array}{c}\text { Purchasing } \\
\text { cost (B) }\end{array}$ & B/A & $\begin{array}{c}\text { Sales } \\
\text { (A) }\end{array}$ & $\begin{array}{c}\text { Purchasing } \\
\text { cost (B) }\end{array}$ & B/A \\
\hline \hline Hyundai & 274,725 & 138,236 & 50.3 & 273,837 & 150,036 & 54.8 \\
Kia & 152,577 & 89,694 & 58.8 & 159,994 & 98,408 & 61.5 \\
GM-Daewoo & 60,516 & 40,831 & 67.5 & 75,313 & 47,890 & 63.6 \\
Ssang yong & 32,979 & 13,697 & 41.5 & 34,355 & 15,645 & 45.5 \\
Renault Samsung & 13,471 & 5,694 & 42.3 & 21,607 & 9,961 & 46.1 \\
\hline
\end{tabular}




\subsection{Features of Logistics in Automotive Industry}

\subsubsection{Complexity of supply chain}

In automotive inbound logistics, there are four major sources of variety which can be summarized as follows: car class, components, suppliers, inbound logistics operations. Out of these sources, particularly, number of suppliers and logistics operations characteristics significantly affects the supply chain complexity. The sourcing from increasing number of suppliers gives a further increase in logistics complexity. In turn, this can lead to a number of additional administrative costs and inefficiencies in the parts delivery system.

In terms of inbound logistics operations, the number of different carriers involved in the inbound logistics process should be considered. In a scenario where each supplier decides on the carrier to be used, there will inevitably be almost as many carriers as suppliers, again leading to a number of disadvantages for the manufacturer.

\subsubsection{Manufacturer's leading position in supply chain}

In the automobile industry, the cooperation among the supply chain members is of greater importance than any other industry. The supplier's poor and inefficient logistics management is directly connected to the vehicle manufacturer's (VM) production problem. VM's efficient and stable production requires components be supplied on time scheduled, and is accomplished through the close relationship between manufacturer and supplier. For instance, a supplier's logistics system (delivery frequency, number of components per delivery) will be restricted by manufacturer's demand, inventory, and production policy. So, separating the manufacturer from the supplier leading logistics system is impossible.

After all, supplier's logistics should be managed as part of the whole automobile logistics process. It can lead to logistics cost reduction, and efficient operation of the assembly line.

\subsubsection{Problems of logistics cost estimation}

Logistics cost estimation should be preceded in order to achieve efficient inbound logistics management. However, this is very difficult in the automobile industry.

Many suppliers share their delivery and demand information, but the information regarding logistics cost has not been shared yet. This becomes one of the causes of insufficient input to cost reduction and joint operation of logistics.

In the case of vehicle manufacturer 'GM-Daewoo' in Korea, we can see the approximate cost of inbound logistics. Manufacturer's inbound logistics cost was $1.6-2.4 \%$ per factory of component cost, indicating that the average logistics cost was $1.9 \%$ of component cost. The components of the inbound logistics cost showed transportation cost was $74 \%$, cost for the input to the line was $18 \%$, and management cost was $7 \%$. 


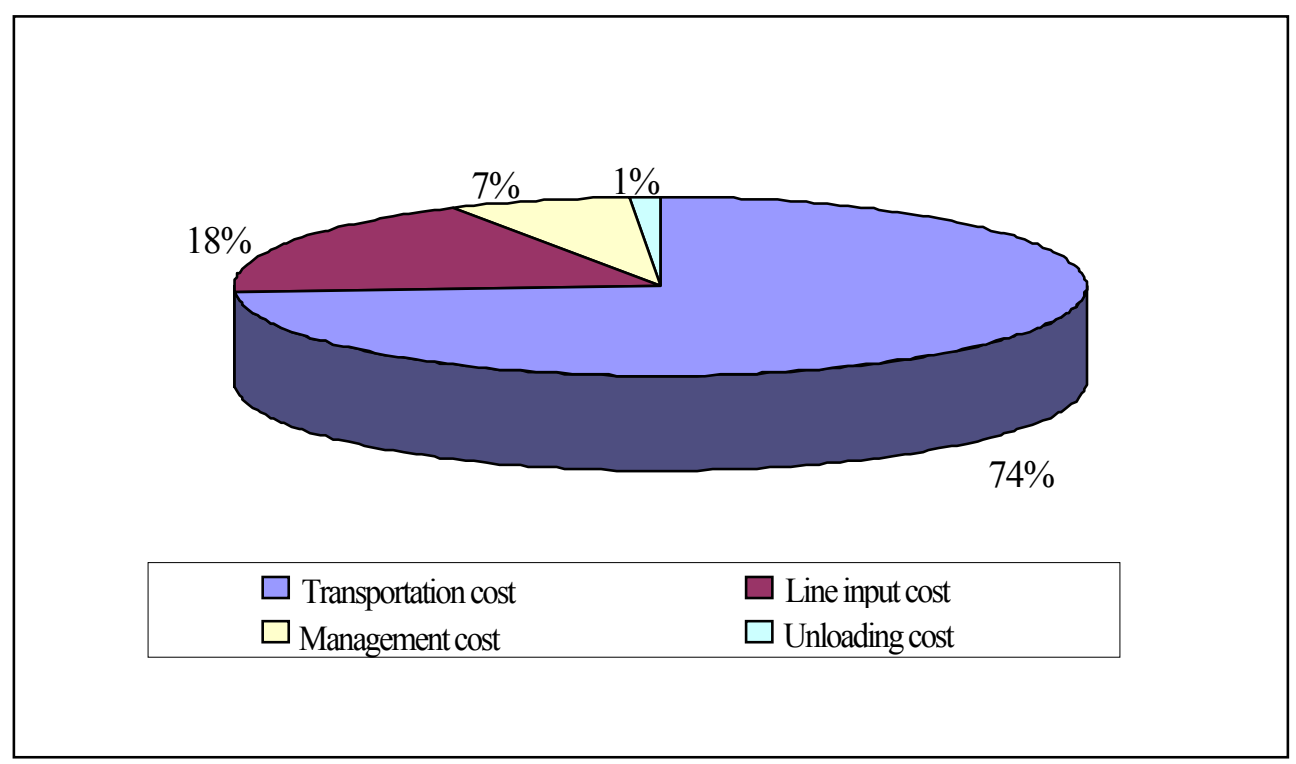

Figure 1. Breakdown of inbound logistics cost

\subsubsection{Inbound Logistics Process}

Automobile logistics process is classified into inbound, production, sales logistics, as shown in figure 2. Inbound logistics flows from parts suppliers to automobile manufacturers, and is divided into domestic inbound logistics and foreign inbound logistics according to part's production location. Domestic inbound logistics (Figure 3) is the flow from domestic suppliers to manufacturers, whereas foreign inbound logistics means supplying parts by importing.

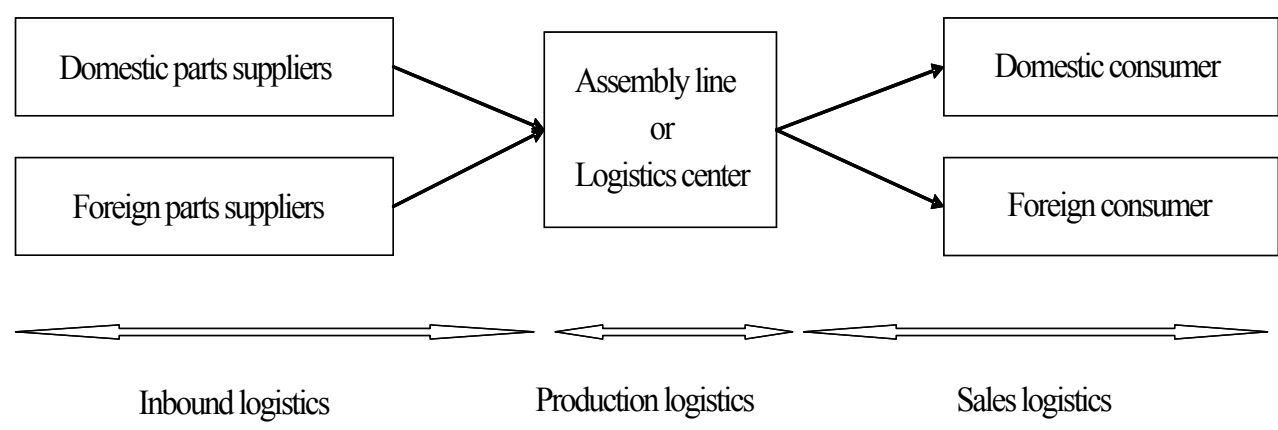

Figure 2. Logistics process of automobile industry 
In the past, vehicle manufacturers were spending too much time on logistics costs on loading and unloading, inventory management, and line input from their employees. This was changed by parts suppliers and logistics service providers. They supply parts whenever necessary without having more inventory than they need. Improved supplier's order fulfillment capability results in reduced inventory. Vehicle manufacturers guarantee continual parts purchasing, instead of shifting the responsibility to suppliers of inventory management and costs caused by frequent deliveries. Therefore parts suppliers subcontract other logistics service providers who can handle loading/unloading, in order to unburden transport costs. Now most of parts suppliers outsource their logistics functions.

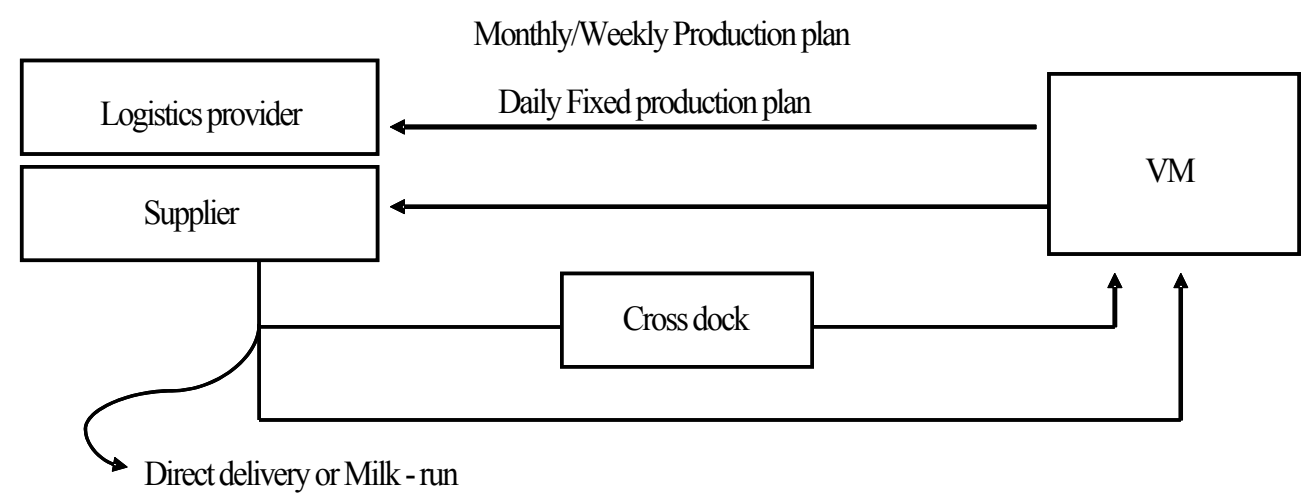

Figure 3. Domestic inbound logistics process

Parts suppliers and logistics service providers depend on demand information. According to demand information, parts suppliers establish a production schedule, and logistics service providers plan for allocation of cars. The problem occurs when demand information varies. Then, it can be solved by inventory possession of parts suppliers and a flexible production system of more expert firms. It can lead to produce as much demand without carrying excess inventory.

There are a number of parts supply methods, such as 'Direct Delivery,' 'Milk Run,' and 'Cross Dock' (called LOC Direct Delivery). Most of the parts suppliers employ 'Direct Delivery' method to meet the high frequency and tight time-window delivery requests. These companies commonly deal with large size parts and large volumes per day. It is not necessary to consolidate because numbers of parts to be loaded on vehicles and loading capacity is maximized. 'Milk Run' or 'LOC Direct delivery' is the process that combines multiple supplier's parts delivered in volume to reduce transport costs and improve loading efficiency. HYUNDAI, KIA and GM DAEWOO MOTORS are trying to expand 'Milk-Run', 'Cross Dock', aimied at cutting logistics costs and improving control ability. 


\subsection{Inbound Logistics in Automobile Industry}

Logistics studies of the Korean automobile industry was rare, but Jung (2001) dealt with suppliers and their logistics in this context. He analyzed the logistics cost of the automobile industry in comparison with Japanese cases. He addressed the reasons why logistics costs were constantly decreasing in Japan, such as logistics outsourcing, reduced manufacturer's logistics management, and human resources costs.

A series of Holweg's studies are more pertinent on this subject. Holweg (2002) analyzed the barriers to the flexible supply chain of the parts. He compared each component's logistics problems, and logistics performance, by classifying each component. Later, Holweg (2003) showed that inbound logistics is critical for a responsive supply chain.

In terms of the performance indicators, Corswant (2002) examined the yearly trend of joint logistics and the high frequency of delivery in the automobile industry. Survey results suggested that vehicle manufacturers and suppliers selected right time, and right quantity delivery factors to be the most important performance indicators. On the other hand, Cooper (1994) emphasized the needs for reducing supply chain complexity in the automobile industry. He insisted that the number of suppliers should be decreased in order to reduce the complexity of the automobile industry. Based on the analysis of the portion of inbound logistics, he suggested that the frequency of delivery by component's sizes and types be well managed to reduce the transportation cost. Tracey (1995) also analyzed the effect of JIT on the supplier and logistics provider. The result indicated that JIT increases their operational performance and transportation cost but reduces inventory.

\subsection{Logistics Performance Evaluation}

Logistics performance evaluation is recognized by its importance and effectiveness. First, it makes possible to trade-off analysis between costs and services. Second, Logistics performance evaluation is directly related to management performance such as profit and market share. Therefore, what to use for evaluation's standards and how to evaluate the standards are important issues for the company.

There have been numerous definitions of 'performance' in the previous studies. This is partly because organizations have multiple and conflicting goals. Someone defined goals as profit. Others may choose goals such as customer service or sales maximization. Also difficulties remain in terms of the tasks of selecting and developing adequate measures for the performance indicators.

Bowersox (1999) suggested Five kinds of logistics performance evaluation criteria; asset management, cost, productivity, quality and customer service. In 1994, PRTM $^{1}$ and some universities suggested the basis of supply chain management (SCM) performance measurement, which are customer satisfaction, time, cost, asset. Chris (1994) similarly suggested 3 dimensions consisting of logistics performance; utilization, productivity, and effectiveness. Utilization factors include labor hours used. Productivity factors include Ton-miles delivered, order process cost, etc.

\footnotetext{
${ }^{1}$ The consulting firm was founded in 1976 in Palo Alto, California. Its founding partners were Theodore Pittiglio, Robert Rabin, Robert Todd, and Michael McGrath. So, the firm is known as PRTM
} 
In particular, effectiveness metrics is used to track availability and timeliness, which in detail, order fill rate, damage rate, perfect delivery, on-time and order cycle time.

Table 3

Logistics performance measurement

\begin{tabular}{|c|c|c|c|}
\hline Author & & Dimensions & Measurement \\
\hline Bowersox & \multirow{4}{*}{$\begin{array}{l}\text { Conceptual } \\
\text { Articles }\end{array}$} & $\begin{array}{l}\text { Cost } \\
\text { Customer service } \\
\text { Productivity } \\
\text { Asset Management } \\
\text { Quality }\end{array}$ & $\begin{array}{l}\text { Cost per unit } \\
\text { Fill rate } \\
\text { Stock outs } \\
\text { Goal programs } \\
\text { Inventory carrying cost } \\
\text { Inventory levels } \\
\text { Number of day's supply }\end{array}$ \\
\hline PRTM & & $\begin{array}{l}\text { Customer service } \\
\text { Quality } \\
\text { Time } \\
\text { Cost } \\
\text { Asset }\end{array}$ & $\begin{array}{l}\text { Fill rate } \\
\text { Customer satisfaction } \\
\text { Quality of goods } \\
\text { Lead time } \\
\text { SCM Cost } \\
\text { Number of day's supply }\end{array}$ \\
\hline Chris & & $\begin{array}{l}\text { Utilization } \\
\text { Productivity } \\
\text { Effectiveness }\end{array}$ & $\begin{array}{l}\text { Labor hours used } \\
\text { Order processing cost } \\
\text { Fill rate } \\
\text { Damage rate } \\
\text { Perfect Delivery } \\
\text { Order cycle time }\end{array}$ \\
\hline Goo & & $\begin{array}{l}\text { Efficiency } \\
\text { Productivity } \\
\text { Asset }\end{array}$ & $\begin{array}{l}\text { Fill rate } \\
\text { Rate of returning } \\
\text { Cost of delivery }\end{array}$ \\
\hline Harrington & \multirow[t]{3}{*}{$\begin{array}{l}\text { Empirical } \\
\text { Studies }\end{array}$} & \multicolumn{2}{|c|}{$\begin{array}{l}\text { Lead time, Lead time variability } \\
\text { Fill rate, Discrepancy rate }\end{array}$} \\
\hline Beak & & $\begin{array}{l}\text { Cost } \\
\text { Customer service }\end{array}$ & $\begin{array}{l}\text { Transportation cost } \\
\text { Fill rate } \\
\text { Number of claims }\end{array}$ \\
\hline Gwag & & $\begin{array}{l}\text { Accuracy } \\
\text { Fill rate } \\
\text { Rate of returning }\end{array}$ & \\
\hline
\end{tabular}




\begin{tabular}{l|l|l}
\hline & & Customer satisfaction \\
Read & Quality & $\begin{array}{l}\text { On-time delivery } \\
\text { Zero defects } \\
\text { Reduction of quality } \\
\text { cost }\end{array}$ \\
\hline
\end{tabular}

More recently, Goo (2005) suggested key performance indicators(KPI) for sales and logistics. Above all, the study focused on the possibility of the most applicable indices to all companies. Indicators were categorized into efficiency, productivity, asset utilization, and each indicator was then divided by its function (i.e. delivery, sales, fleet management, warehousing, transportation). On the other hand, Beak (2004) measured logistics cost and customer services as a logistics performance. Cost dimensions are measured by unloading cost and transportation cost, and customer service dimensions are measured by fill rate and number of claims. Gwag (2000) analyzed a correlation between the SCM system and logistics performance. She measured logistics performance by order processing accuracy, fill rate, and the rate of returning.

Previous discussions on the measurement of logistics performance are summarized in table 3.

\section{Methodology}

In this section, the variables included in this study are introduced first. Secondly, the research framework and each hypothesis are presented. Then statistical methods involved in the hypotheses testing will be summarized in the last part. .

\subsection{Variables}

\subsubsection{Supplier's type of logistics}

The supplier's type of logistics service is defined by case study and supplier interview. In the automobile industry, there are three kinds of logistics types. The first case is direct control (1PL, 2PL). It means that they operate their logistics directly. The second case is the outsourcing of their logistics to the external logistics provider, and they have the right to select a logistics provider (Outsourcing 1). The last case is outsourcing their logistics to the external logistics provider. In this case they don't have the right to select the logistics provider but the right of logistics provider selection belongs to the vehicle manufacturer (Outsourcing 2).

\subsubsection{Company size}

According to the size of the companies, first suppliers in Korea mobile industry are categorized into three classes. Its scale of sales made from the Korea Auto Industry Coop. Association; small- 
sized suppliers selected by sales, less than 20 billion won in 2005; medium-sized suppliers selected by sales, ranged from 20 to 40 billion won; and large-sized suppliers selected by sales, more than 40 billion won.

\subsubsection{Logistics performance evaluation}

Logistics performance evaluation indicators are based on Bowersox's study, because of the suitability, wide use, and survey efficiency. The selected measures are shown in table 4.

Table 4

Selected logistics performance evaluation indicators

\begin{tabular}{l|l}
\hline & \\
\hline \hline Cost & Leasures \\
\hline Customer Service & On-time delivery, Rate of stock out \\
\hline Productivity & Comparison to Historical standards, Goal programs \\
\hline Asset Management & Inventory carrying cost, Inventory levels, Number of day's supply \\
\hline Quality & Frequency of damage, Cost of returned goods \\
\hline
\end{tabular}

\subsubsection{Actual logistics performance}

Actual logistics performance measures were chosen by their comparability. Many performance measures could not be compared easily when different characteristics of suppliers and parts were involved. Therefore, extra caution was given to select measurable and comparable indicators of actual logistics performance.

Consequently, four items were chosen to measure actual logistics performance; order fill rate, number of returning items, number of delivery errors, and days of stock. Among them, the number of returning items and delivery errors were measured on a 5-point scale, and order fill rate and the number of days supply were measured on a 6-point scale.

\subsection{Research Framework and Hypotheses}

Research framework and hypotheses are presented in figure 4. In detail, hypotheses are as follows. 


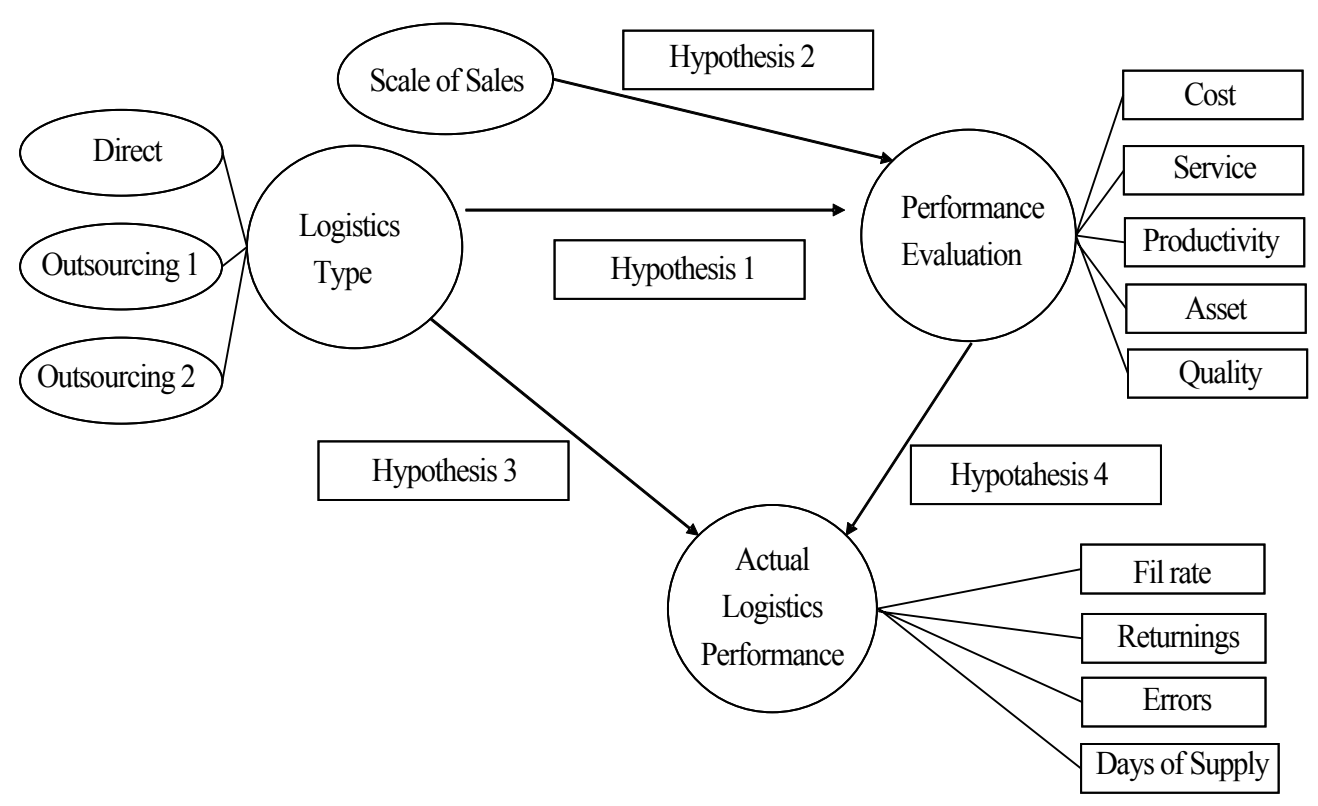

Figure 4. Research framework and hypotheses

Hypothesis 1. Performance evaluation levels will differ among supplier's logistics types.

Hypothesis 2. Performance evaluation levels will differ among supplier's scale of sales.

Hypothesis 3. Actual logistics performance will differ among supplier's logistics types.

Hypothesis 4. There will be a positive correlation between actual logistics performance and performance evaluation levels.

\subsection{Statistical methodology}

To test the differences in performance evaluation criteria or in actual logistics performance depending upon the suppliers' logistics types or sales scale (hypothesis 1, 2, and 3), analysis of variance (ANOVA) was used. In terms of hypothesis 4, Pearson correlation was used to check the significant level of the correlation between performance evaluation criteria and actual performance level. The internal consistency of scale items for each variable dimension was also checked by using Cronbach's alpha. 


\section{Analysis and findings}

\subsection{Survey instrument and data collection}

The survey was constructed based on suppliers' current logistics status, actual logistics performance, and their logistics performance evaluation criteria. Survey questions were designed based on literature review and supplier interviews.

For supplier sample, suppliers for Hyundai/Kia(n=400) and suppliers for Reanult Samsung's $(\mathrm{n}=145)$ were used as a sample frame. This list was acquired from each company's purchasing and logistics staffs. Then, samples were randomly selected as 150 for Hyundai/Kia and 50 for Reanult Samsung from the list.

To increase response rate, contact was made by phone first. And then, e-mail was sent to the suppliers who responded to the first contact. The number of responses and response rates are shown in table 5.

Table 5

Breakdown of response

\begin{tabular}{l|c|c|c|c}
\hline & $\begin{array}{c}\text { Survey } \\
\text { mailed }\end{array}$ & Received & $\begin{array}{c}\text { Response } \\
\text { Rate }\end{array}$ & $\begin{array}{c}\text { Cumulative Response } \\
\text { Rate }\end{array}$ \\
\hline \hline First mailing & 200 & 33 & $16.5 \%$ & $16.5 \%$ \\
Second mailing & remain 167 & 37 & $22.16 \%$ & $35 \%$ \\
Total & 200 & 70 & & $35 \%$ \\
\hline
\end{tabular}

The first suppliers sales in 2005 are divided into three categories (less than 200, 200-400, more than 400 hundred million won). The majority was more than 400 hundred million won sales group (64.3\%); the next group is 200-400 hundred million won sales group (30\%); less than 200 hundred million won sales groups only occupied $5.7 \%$. The number of employees is also divided into three categories (less than 50, 50-300, more than 300). The majority was the 50-300group (50\%); the more than 300 employees group was shown to be similar (47.1\%). Only $2.9 \%$ of suppliers have less than 50 employees (Table 6). 
Table 6

Company data(1st suppliers)

\begin{tabular}{l|l|c|c}
\hline \multicolumn{2}{l|}{} & Numbers & Percent(\%) \\
\hline \hline \multirow{2}{*}{$\begin{array}{l}\text { Sales in 2005: } \\
\text { billion won } \\
(\mathrm{n}=70)\end{array}$} & less than 20 billion & 4 & $5.7 \%$ \\
\cline { 2 - 4 } & $20-40$ billion & 21 & $30.0 \%$ \\
\cline { 2 - 4 } & more than 40 billion & 45 & $64.3 \%$ \\
\hline $\begin{array}{l}\text { Number of employee } \\
(\mathrm{n}=70)\end{array}$ & less than 50 & 2 & $2.9 \%$ \\
& $50-300$ & 35 & $50.0 \%$ \\
& more than 300 & 33 & $47.1 \%$ \\
\hline
\end{tabular}

\subsection{Hypothesis testing}

\subsubsection{Reliability analysis}

As is the norm with quantitative analysis incorporating scaled responses, a test of reliability was performed using Cronbach's Alpha. Table 7 shows the results of the reliability test of the five major constructs. All five had alpha greater than 0.60 (cost .784, customer service .900 , productivity .935 , asset utilization .865 , quality .835 ) and therefore, all constructs showed strong internal consistency.

Table 7

Reliability analysis for performance evaluation factor

\begin{tabular}{l|c}
\hline & Cronbach's $\alpha$ \\
\hline \hline Cost & .784 \\
\hline Customer service & .900 \\
\hline Productivity & .935 \\
\hline Asset utilization & .865 \\
\hline Quality & .835 \\
\hline
\end{tabular}




\subsubsection{Hypothesis testing}

One-way ANOVA was used to test the differences in performance evaluation criteria depending upon the logistics types (hypothesis 1). Even with the existence of small differences in the averages, there were no significant differences about performance evaluation levels depending upon each logistics types. However, the Outsourcing 1 records the highest average of the performance evaluation levels except Asset factors. In the Asset, Outsourcing 2 is a little higher than Outsourcing 1.

Table 8

Logistics service types and performance evaluation level

\begin{tabular}{|c|c|c|c|c|c|c|}
\hline & & $\mathrm{N}$ & Average & Std.Dev & $\mathrm{F}$ & $\mathrm{p}$-value \\
\hline \multirow{3}{*}{ Cost } & Outsourcing 1 & 36 & 3.3056 & 68949 & \multirow{3}{*}{.207} & \multirow{3}{*}{.814} \\
\hline & Outsourcing 2 & 18 & 3.2778 & .42779 & & \\
\hline & Direct & 16 & 3.1875 & .60208 & & \\
\hline \multirow{3}{*}{$\begin{array}{l}\text { Customer } \\
\text { Service }\end{array}$} & Outsourcing 1 & 36 & 3.3333 & .76532 & \multirow{3}{*}{.358} & \multirow{3}{*}{.701} \\
\hline & Outsourcing 2 & 18 & 3.3056 & .64486 & & \\
\hline & Direct & 16 & 3.1563 & .62500 & & \\
\hline \multirow{3}{*}{ Productivity } & Outsourcing 1 & 36 & 3.3750 & 69050 & \multirow{3}{*}{2.054} & \multirow{3}{*}{.136} \\
\hline & Outsourcing 2 & 18 & 3.1389 & .33456 & & \\
\hline & Direct & 16 & 3.0000 & .81650 & & \\
\hline \multirow{3}{*}{ Asset } & Outsourcing 1 & 36 & 3.2037 & .66322 & \multirow{3}{*}{.571} & \multirow{3}{*}{.568} \\
\hline & Outsourcing 2 & 18 & 3.2407 & .61363 & & \\
\hline & Direct & 16 & 3.0208 & 67185 & & \\
\hline \multirow{3}{*}{ Quality } & Outsourcing 1 & 36 & 3.5556 & .80868 & \multirow{3}{*}{1.042} & \multirow{3}{*}{.358} \\
\hline & Outsourcing 2 & 18 & 3.5278 & .49918 & & \\
\hline & Direct & 16 & 3.2500 & .73030 & & \\
\hline
\end{tabular}

The relationship between suppliers' scale of sales and performance evaluation criteria (hypothesis 2) was also tested by ANOVA (table 9).

In all five performance evaluation parts, customer service $(\mathrm{F}=2.296, \mathrm{p}<.01)$, productivity $(\mathrm{F}=3.423, \mathrm{p}<.05)$, asset $(\mathrm{F}=7.369, \mathrm{p}<.01)$ and, quality $(\mathrm{F}=13.987, \mathrm{p}<.001)$ showed significant differences in performance evaluation criteria among suppliers' scale of sales. In addition, Scheffe method was used for multiple group comparison. Customer Service Asset appeared significantly different between the less than 20billion sales group and the more than \$40billion sales group. 
Productivity didn't showed significant differences. Quality appeared significantly different between the less than 40 billion won sales groups and the more than 40 billion won sales group.

Overall, the more that sales increases, the more that improvement occurs in the performance evaluation criteria. It, especially, occurred in the Customer Service, Asset, and Quality levels.

Table 9

Company size and performance evaluation level

\begin{tabular}{|c|c|c|c|c|c|c|c|}
\hline & & $\mathrm{N}$ & Average & Std.Dev & $\mathrm{F}$ & p-value & Scheffe \\
\hline \multirow{3}{*}{ Cost } & less than 20billion & 4 & 2.8750 & .25000 & \multirow{3}{*}{2.296} & \multirow{3}{*}{.109} & \\
\hline & 20 40 billion & 21 & 3.1190 & .38421 & & & \\
\hline & more than 40billion & 45 & 3.3778 & 68387 & & & \\
\hline \multirow{3}{*}{$\begin{array}{l}\text { Customer } \\
\text { Service }\end{array}$} & less than 20billion & 4 & 2.5000 & .57735 & \multirow{3}{*}{$7.295^{* *}$} & \multirow{3}{*}{.001} & $\mathrm{a}$ \\
\hline & 20 40 billion & 21 & 3.0000 & .31623 & & & $a b$ \\
\hline & more than 40billion & 45 & 3.4889 & .74992 & & & $\mathrm{~b}$ \\
\hline \multirow{3}{*}{ Productivity } & less than 20billion & 4 & 3.0000 & .00000 & \multirow{3}{*}{$3.423 *$} & \multirow{3}{*}{.038} & \\
\hline & 20 40 billion & 21 & 2.9524 & .47183 & & & \\
\hline & more than 40billion & 45 & 3.3778 & .72422 & & & \\
\hline \multirow{3}{*}{ Asset } & less than 20billion & 4 & 2.5833 & .50000 & \multirow{3}{*}{$7.369 * *$} & \multirow{3}{*}{.001} & $\mathrm{a}$ \\
\hline & 20 40 billion & 21 & 2.8571 & .47809 & & & $a b$ \\
\hline & more than 40billion & 45 & 3.3704 & .64832 & & & $\mathrm{~b}$ \\
\hline \multirow{3}{*}{ Quality } & less than 20billion & 4 & 2.7500 & .50000 & \multirow{3}{*}{$13.987^{* * *}$} & \multirow{3}{*}{.000} & $\mathrm{a}$ \\
\hline & 20 40 billion & 21 & 3.0000 & .44721 & & & $\mathrm{a}$ \\
\hline & more than 40billion & 45 & 3.7667 & .68755 & & & $\mathrm{~b}$ \\
\hline
\end{tabular}

Notes: ${ }^{*} \mathrm{p}<.05, * * \mathrm{p}<.01, * * * \mathrm{p}<.001$

Table 10 shows the result of One-way ANOVA between the supplier's logistics types and actual logistics performance (hypothesis 3 ).

In terms of the number of returns, 'Outsourcing 1' was 1.78 per month in average, 'Outsourcing 2' was 1.72 per month, and 'Direct' was 2.18. But, there were no statistical significant differences among them. Likewise, the days of stock has no significant differences among groups. However, there were significant differences among groups $(\mathrm{F}=21.408, \mathrm{p}<.001)$ in terms of the order fill rate; 'Outsourcing 1' was 4.72, 'Outsourcing 2' was 4.0, 'Direct' was 2.31. It means that Outsourcing 1 type accomplished almost 100\% in the order fill rate, Outsourcing 2 is $99 \%$, Direct 
is $97 \%$ on average. The number of delivery errors also showed significant differences ( $\mathrm{F}=40.035$, $\mathrm{p}<.001$ ); 'Outsourcing 1' was 1.22, 'Outsourcing 2' was 1.78, 'Direct' was 3.38.

Table 10

Logistics types and actual logistic performance

\begin{tabular}{l|l|c|c|c|c|c|c}
\hline \multicolumn{2}{l}{} & $\mathrm{N}$ & Average & Std.Dev & $\mathrm{F}$ & p-value & Scheffe \\
\hline \hline \multirow{3}{*}{ Returns } & Outsourcing 1 & 36 & 1.7778 & .83190 & & & \\
& Outsourcing 2 & 18 & 1.7222 & .89479 & 1.323 & .273 & \\
& Direct & 16 & 2.1875 & 1.16726 & & & \\
Fill rate & Outsourcing 1 & 36 & 4.7222 & 1.23314 & & & $\mathrm{a}$ \\
& Outsourcing 2 & 18 & 4.0000 & 1.23669 & $21.408^{* * *}$ & .000 & $\mathrm{a}$ \\
& Direct & 16 & 2.3125 & 1.19548 & & & $\mathrm{~b}$ \\
\hline \multirow{3}{*}{ Delivery Errors } & Outsourcing 1 & 36 & 1.2222 & .42164 & & & $\mathrm{a}$ \\
& Outsourcing 2 & 18 & 1.7778 & .94281 & $40.035^{* * *}$ & .000 & $\mathrm{a}$ \\
& Direct & 16 & 3.3750 & 1.20416 & & & $\mathrm{~b}$ \\
\hline \multirow{3}{*}{$\begin{array}{l}\text { Days of } \\
\text { Stock }\end{array}$} & Outsourcing 1 & 36 & 3.0833 & 1.44173 & & & \\
& Outsourcing 2 & 18 & 2.7222 & 1.27443 & 1.454 & .241 & \\
\hline
\end{tabular}

Note: ${ }^{* * *}<.001$

The correlation analysis was performed to define the relationship between actual logistics performances and performance evaluation levels (hypothesis 4). The correlation between logistics performance (the number of returning items, order fill rate, the number of delivery errors, a days of stock) and performance evaluation level (cost, customer service, productivity, asset utilization , quality) are shown in table 11.

Table 11

The correlation between actual logistics performance and performance evaluation level

\begin{tabular}{l|c|c|c|c|c|c|c|c|c}
\hline & returning & fill rate & errors & $\begin{array}{c}\text { days of } \\
\text { supply }\end{array}$ & cost & service & productivity & asset & quality \\
\hline \hline returning & 1 & & & & & & & & \\
\hline fill rate & -.132 & 1 & & & & & & & \\
\hline
\end{tabular}




\begin{tabular}{|c|c|c|c|c|c|c|c|c|c|}
\hline errors & $\begin{array}{c}.441 \\
(* * *) \\
\end{array}$ & $\begin{array}{r}-.560 \\
(* * *) \\
\end{array}$ & 1 & & & & & & \\
\hline $\begin{array}{l}\text { days of } \\
\text { supply }\end{array}$ & .149 & -.213 & $\begin{array}{c}.270 \\
(*)\end{array}$ & 1 & & & & & \\
\hline cost & .005 & $\begin{array}{c}.298 \\
(*) \\
\end{array}$ & -.170 & .068 & 1 & & & & \\
\hline service & -.061 & $\begin{array}{c}.493 \\
(* * *)\end{array}$ & -.157 & .007 & $\begin{array}{c}.592 \\
(* * *) \\
\end{array}$ & 1 & & & \\
\hline productivity & -.230 & $\begin{array}{l}.321 \\
(* *) \\
\end{array}$ & $\begin{array}{c}-.392 \\
(* *) \\
\end{array}$ & $\begin{array}{c}-.243 \\
(*) \\
\end{array}$ & $\begin{array}{r}.456 \\
(* * *) \\
\end{array}$ & $\begin{array}{c}.482 \\
(* * *) \\
\end{array}$ & 1 & & \\
\hline asset & -.123 & $\begin{array}{l}.344 \\
(* *) \\
\end{array}$ & $\begin{array}{c}-.286 \\
(*)\end{array}$ & $\begin{array}{l}-.475 \\
(* * *) \\
\end{array}$ & $\begin{array}{r}.476 \\
(* * *) \\
\end{array}$ & $\begin{array}{r}.678 \\
(* * *) \\
\end{array}$ & $\begin{array}{r}.559 \\
(* * *) \\
\end{array}$ & 1 & \\
\hline quality & $\begin{array}{l}-.463 \\
(* * *)\end{array}$ & $\begin{array}{l}.330 \\
(* *)\end{array}$ & $\begin{array}{c}-.273 \\
(*)\end{array}$ & .071 & $\begin{array}{l}.385 \\
(* *)\end{array}$ & $\begin{array}{c}.598 \\
(* * *)\end{array}$ & $\begin{array}{l}.387 \\
(* *)\end{array}$ & $\begin{array}{c}.537 \\
(* * *)\end{array}$ & 1 \\
\hline
\end{tabular}

Notes: ${ }^{*} \mathrm{p}<.05, * * \mathrm{p}<.01, * * * \mathrm{p}<.001$

Quality and delivery errors were shown shaving a high negative correlation, suggesting that if the quality level increased more, the number of returns listed decreased more. On the other hand, Customer Service and order fill rate were shown having a high positive correlation, indicating that if there is more of an increase in customer service, there is more of an increase in the order fill rate. Productivity and asset utilization also showed weak correlations with the order fill rate. The relationship between the number of delivery errors and productivity was weak but positive, and the relationship between asset utilization and a days of stock was strong and negative.

In conclusion, as performance evaluation criteria increased, the number of returning items and a days of supply decreased but order fill rate was increased. So, it can be concluded that actual logistics performance has a close relationship with performance evaluation level.

\subsection{Other findings}

From the result of the interview and survey, The first supplier's current status and characteristics were discovered. First, the tendency of suppliers' business network expansion were discovered. In 2001, the majority of suppliers(55.4\%) had only one VM customer. From the survey, the majority have more than $3 \mathrm{VM}$ customers. It shows the trend of the supplier's diversity of VM customers. Secondly, the tendency of the supplier's logistics outsourcing is presented. A majority of suppliers $(77.1 \%)$ used a logistics service provider. In the past, many supplier's logistics were performed simply by leasing vehicles, or they controlled their own. Third, there were many problems to right time delivery. Suppliers suffered from the VM's variation of demand. And second supplier's unstable supply was also at issue. They didn't have any trouble with their capacity. Fourth, suppliers increasingly want to control their own logistics. The reasons for this was 'Distrust 
to 3PL', and 'Cost reduction'. The question for reasons of outsourcing were like other research's 3PL selection factors. 'Cost reduction' is a main reason for logistics outsourcing. 'Customer service', 'Controlled by VM', 'Core competence' occupied a similar portion of responses.

\section{Conclusion}

In this paper, a survey was conducted of the first suppliers in the automobile industry regarding the logistics service including types, performance measures and actual performance. And several hypotheses were presented and tested.

In terms of the hypothesis testing, there was no significant difference regarding performance evaluation levels for each logistics types. However, Customer service, Asset, Quality levels in performance evaluation criteria showed significant differences among sales groups. There were also differences among the types of logistics in terms of the actual logistics performance. Suppliers who outsource the logistics showed better actual logistics performances. Finally, actual logistics performance had a correlation with performance evaluation levels.

The sample used in this study was only 70 first supplier companies, even though the number was enough to perform statistical tests. Therefore, a more extensive survey will help to validate the findings of this study. It should be also noted that the logistics cost analysis was limited, because the logistics cost is determined by kind of parts, sizes, and weights. A more rigorous and elaborate study, including various product categories, will also enhance the validity of this study.

\section{Acknowledgements}

This work was supported by INHA UNIVERSITY Research Grant 32762-01.

\section{References}

Beak, Y.M. 2004. Introduction of EDI and its Effects to Performance. Ph.D. Thesis: The Univ. of Hannam.

Bowersox, D.J. and D.J. Closs. 1999. Logistical Management: The Integrated Supply Chain Process. McGraw-Hill.

Chris, C. and S. Yossi. 1994. A review and evaluation of logistics metrics. The International Journal of Logistics Management. 5: 3-12.

Cho, C. 2004. The Changes of Component Supply System. Korea Institute for Industrial Economics and Trade : 76-98. 
Cooper, J. and J. Griffiths. 1994. Managing Variety in Automotive Logistics with the Rule of Three. The International Journal of Logistics Management. 5: 29-40.

Corswant, F. and P. Fredriksson. 2002. Sourcing trends in the car industry: a survey of car manufactuers' and suppliers' strategies and relations. International Journal of Operations and Production Management. 22(7): 741-758.

Gwag, B.S. 2000. Correlation between the SCM system and logistics performance. Ph.D. Thesis. The Univ. of Daegoo Catholic.

Hamilton, L. 1995. Data Analysis for Social Scientists. Duxbury Press.

Harrington, T.C., D.M. Lambert and M. Christopher. 1991. A Methodology for Measuring Vendor Performance. Journal of Business Logistics. 12(1).

Holweg, M. 2002. The 3day car component supplier study: investigating the implications of reponsive vehicle supply on the component supply chain. Lean Enterprise Research Centre.

Holweg, M. and J. Miemczyk. 2003. The Strategic Implications for Automotive Logistics Operations. Journal of Purchasing \& Supply Management. 9(2): 63-71.

Holweg, M. 2005. An Investigation into Supplier Responsiveness. The International Journal of Logistics Management. 16(1): 96-119.

Jung, J.S. 2001. Logistics innovation of automotive industry. Korea Institute for Industrial Economics and Trade: 74-80.

Lee, H.S. 2004. Strategic Alliance between 3PL and an Automobile manufacturer. Marketing Management Research. 9(3):159-180.

PRTM. 1994. Integrated supply chain performance measurement: a multi-industry consortium recommendation.

Read, W.F. and M.S. Miller. 1990. The state of quality in logistics. International Journal of Physical Distribution and Logistics Management. 21(6):32-47.

Tracey, M., L.T. Chong, M. Vonderembse, and E.J. Bardi. 1995. A Reexamination of the Effects of Just-In-Time on Inbound Logistics. The International Journal of Logistics Management. 6: 25-38.

www.kaica.or.kr

www.tntlogistics.com 